\title{
Perspectives for the Use of Quantitative Genetics in Breeding of Autogamous Plants
}

\author{
Magno Antonio Patto Ramalho, Bruna Line Carvalho, and José Airton Rodrigues Nunes \\ Department of Biology, Genetics and Breeding of Plants Sector, Federal University of Lavras (UFLA), \\ 37200-000 Lavras, MG, Brazil \\ Correspondence should be addressed to Magno Antonio Patto Ramalho; magnoapr@dbi.ufla.br
}

Received 30 May 2012; Accepted 4 October 2012

Academic Editors: B. Chen, V. Mohler, and A. Yamamoto

Copyright (c) 2013 Magno Antonio Patto Ramalho et al. This is an open access article distributed under the Creative Commons Attribution License, which permits unrestricted use, distribution, and reproduction in any medium, provided the original work is properly cited.

\begin{abstract}
With the increased demand for food, the use of methods and alternatives that increase efficiency in selection of inbred lines is necessary. The use of quantitative genetics plays an important role in this respect, especially when the pedigree method is used in autogamous plants. This study proposes the inclusion of relationship information among progenies using the best linear unbiased predictor (BLUP) to obtain the breeding values of greater accuracy and, consequently, increase genetic gains from the selection. A strategy is proposed that aims to accelerate the program of obtaining perennial plant inbreds and use the greatest amount of information possible in selection so as to attain maximum accuracy. In that way, it would be possible to make inbreds available which are better than the existing ones, with greater frequency, meeting the agribusiness demand involved in production of perennial plants.
\end{abstract}

\section{Introduction}

Plants considered to be autogamous are those in which self-fertilization is predominant, that is, the rate of crossfertilization is less than 5\% [1]. Strategies particular to the mode of reproduction are used in breeding these plants. Available information indicates that breeding of this type of plant has been successful in different regions of the world [24].

The two most traditional methods for conducting with segregating progenies of autogamous plants, the bulk method and pedigree method, were proposed in Europe at the end of the 19th century and beginning of the 20th century [5]. After that, other selection methods were proposed, aiming to reduce the deficiencies of the two methods mentioned above. Among them, the bulk method within progenies $\mathrm{F}_{2}$ or $\mathrm{F}_{3}$ [6] and the single seed descendent (SSD) [7-9] have also been widely used. Comparisons among these methods have been performed over time and, although in some cases differences have been detected among them [10-12], what is observed is that if they are well applied, all of them are efficient.
It may be inferred that, even though it has occurred in some cases [13-15], the use of quantitative genetics for assisting breeders of autogamous plants has been much less than that used for alogamous plants [16, 17]. Along with the population growth expected for the coming decades, the demand for food will have expressive growth $[18,19]$. As there is no longer great availability of noncropped land, the main option for meeting the demand for grains, fruit, and fibers is by means of increasing yield.

One of the alternatives for increasing yield is by means of improvements in crop management. This is the context for use of an increasing quantity of fertilizers, pesticides, and irrigation water. Nevertheless, there are some restrictions on the growing use of these inputs; some through restriction in availability and price and others through issues related to possible environmental impacts.

Thus, the expectation is that the increase in yield may be obtained especially through genetic improvement. In this context, some new alternatives are being proposed with a view toward assisting identification of inbreds that are more and more efficient. One of these options is more accentuated 


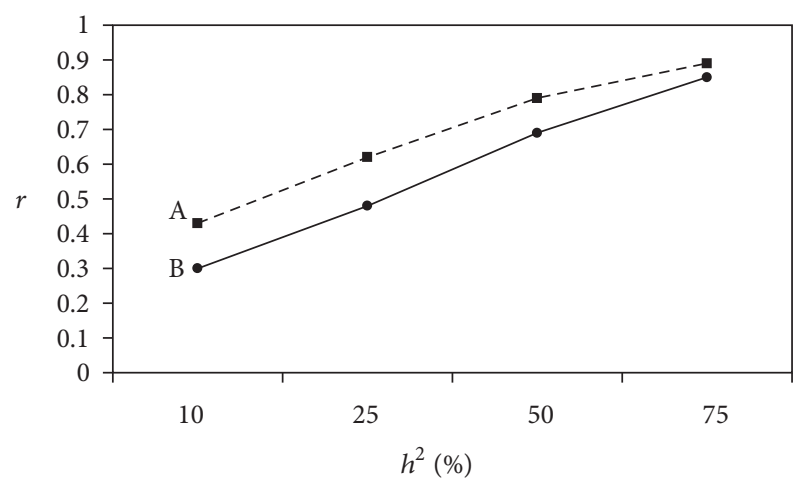

Figure 1: Mean values of the Spearman correlations $(r)$ between additive genetic values (AGV) and BLUP predictions, considering (A) and ignoring (B) the additive genetic relationship among $\mathrm{F}_{4: 5}$ progenies, conducted by the pedigree method for different heritability values in the mean of the progenies $\left(h^{2}\right)$ (adapted from [21]).

use of knowledge from biometrics/quantitative genetics. In this study, some of the possibilities for use of quantitative genetics will be discussed, with emphasis on breeding of autogamous plants, above all, when the pedigree method is used.

\section{Improving the Efficiency of the Pedigree Method}

The pedigree method is the most used method in breeding of autogamous plants and the methodology used is found in many publications $[6,8,20]$. What is to be discussed is a strategy for improving its efficiency. Among the advantages of the pedigree method, that which is always cited is that it allows one to obtain the degree of coancestry among generations, in other words, one has the genealogy of the selected inbreds. This information is almost always obtained; however, its use, when this occurs, is very restricted. It should have more expressive use, above all due to the work involved in obtaining it, with a view toward improving the efficiency of the method.

An alternative for use of genealogy was presented by [21] using computer simulation. A quantitative trait with inheritance was considered in accordance with a purely additive genetic model; in other words, absence of dominance and epistasis. The authors used a model with 20 segregating loci of independent assortment, with equal effects, in a diploid individual, and allele frequency of 0.5 . The influence of environmental effects on forming phenotypes was observed in considering different heritability values $\left(h^{2}=10 \%, 25 \%\right.$, $50 \%$ and $75 \%$ ). For each heritability, $1000 \mathrm{~F}_{2}$ segregating populations were simulated, which were conducted following that recommended by the pedigree method. From each $\mathrm{F}_{2}$ population, 64 plants were chosen, which constituted 64 progenies $\mathrm{F}_{2: 3}$ in the following generation, $\mathrm{F}_{3}$. From each $\mathrm{F}_{2: 3}$ progeny, two plants were taken, forming 128 progenies $\mathrm{F}_{3: 4}$ in the following generation. This process was repeated for one more generation, generating $256 \mathrm{~F}_{4: 5}$ progenies.

The $\mathrm{F}_{4: 5}$ progenies were assessed in experiments with replication $(r=2)$ in a completely randomized design (CRD), without loss of generality, and a plot consisting of 20 plants. The phenotypic data were analyzed by the mixed model approach with and without incorporation of information from the genealogical records. The manner in which this information is taken into account in the analytical procedure occurs through computation of the genetic relationship matrix among the progenies. The non-additive effects were not considered in the model; thus, the matrix of the additive genetic relationships was obtained by two times Malecot's coancestry coefficients. These coefficients may easily be obtained via available software. Detailed description regarding Henderson's mixed model procedure may be seen in textbooks [22-25]. The selection method under a mixed model for the case of random genetic treatments, as in this study with random progenies, uses BLUP (best linear unbiased prediction) as a predictor of such effects.

BLUP predictions of the additive genetic values are said to present better predictive accuracy in relation to other predictors/estimators, like BLUE (best linear unbiased estimator), which are estimators of the additive genetic values (AGV) under fixed genetic treatments. Thus, it may be inferred that BLUP and BLUE are both a function of phenotypic data and that they have a common purpose. In this case, one must choose the estimator/predictor that provides for ranking of the predicted AGV as near as possible to the real [26] without, however, going against philosophical principles of genetics and breeding, as well as statistics and experimentation, which direct such a choice.

Two models were considered in the simulation: a model with insertion of coancestry and a second model ignoring such information. From these models, one has BLUPA and BLUPI, respectively, as predictors of the AGV.

By means of the simulations, it was observed that inclusion of coancestry information among the progenies in all heritability situations $\left(h^{2}\right)$ resulted in more accurate predictions of the AGVs (Figure 1), culminating in ranking of the progenies nearest to the true ranking based on the real AGVs simulated. Nevertheless, it should be emphasized that this selective advantage was more expressive under low heritability $\left(10 \leq h^{2} \leq 50 \%\right)$. Heritability is a highly useful parameter for the breeder because it reflects the reliability one has in the phenotypes observed for indicating genotypically superior individuals. Decrease in heritability indicates that the phenotype becomes a poor indicator of the genotypic value due to the pronounced effect of environmental factors, reducing the gain from selection (Figure 2). The purpose of the use of BLUP is to provide better adjustment of the phenotypic value to the nongenetic effects by shrinkage effect towards the expected genetic values. Under balanced conditions, the shrinkage factor is heritability, showing that although the mixed model procedure is essentially statistical, there is strong association and meaning of the estimators with that desired by the breeder and with parameters routinely used in breeding activities. 


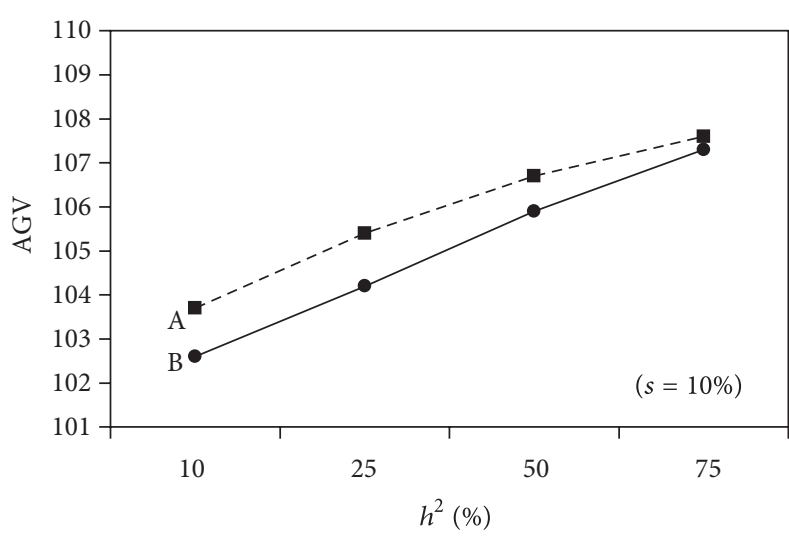

(a)

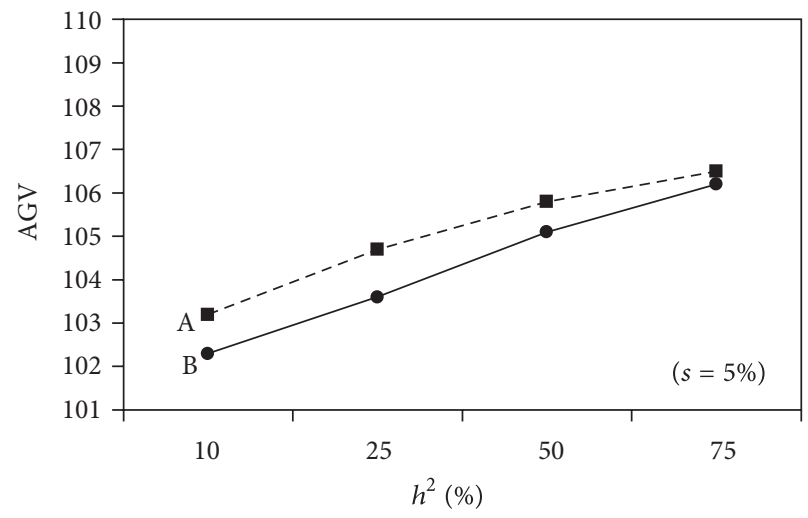

(b)

FIGURE 2: Mean additive genetic values (AGV) of the $\mathrm{F}_{4: 5}$ progenies selected by BLUP considering (a) and ignoring (b) the information from the additive relationship in terms of heritability in the broad sense in the mean of the progenies $\left(h^{2}\right)$ and selected proportions (s) of 5\% and $10 \%$ (adapted from [21]).

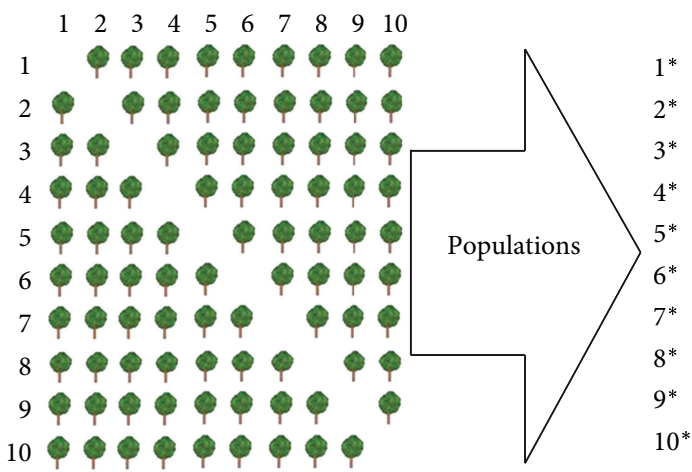

FIGURE 3: A proposal for obtaining the segregating population. In the example, ten top crosses will be obtained and the $F_{1}$ seed obtained would be mixed in equal proportion.

From the above, it may be concluded that the BLUP predictions of the progenies reflected the expected or predicted genetic gains in the populations from breeding. When information from genealogy was considered, the genetic gains were generally of greater magnitude than those achieved when this information was ignored, regardless of the intensity of selection. Nevertheless, corroborating what had already been mentioned, the additional genetic gains were relatively more expressive under low heritability (Figure 2).

Thus, for the purpose of maximizing genetic gains when using the pedigree method, exploiting the information from the genealogical records at the time of selection through use of the mixed model statistical approach is recommended. It is worth emphasizing that success in selection of superior progenies is intrinsically connected with adequate experimentation, since for statistical analysis to result in good predictions of BLUP, having good estimates of genetic and environmental variances is indispensable. In addition, it is well known that at the time of analysis, the phenotypic data invariably have greater weight in relation to the extra information incorporated, such as coancestry.

\section{Strategies for Perennial Plant Breeding in the Pedigree Method.}

The comments to be made will have an emphasis on coffee crop (Coffea arabica), but may be extrapolated to any perennial autogamous plant. Coffee was chosen because it is a species of great social and economic importance in Brazil. Breeding programs are conducted exclusively by the public sector. The breeding methodology used until then was by means of conducting segregating populations by the pedigree method [27, 28].

It is known that the main difficulty in genetic breeding of any species is reducing the effect of the environment and genotype by environment interaction on phenotypic expression, in other words, having a good representative of the genotype in the phenotype $[9,29]$. In a perennial plant, like coffee crop, this factor is even more expressive because the plant has a long juvenile period and marked annual yield oscillation, with various years of assessment being necessary [30]. What is being proposed is a strategy that seeks to accelerate the program for obtaining new inbreds and, at the same time, use the most information possible in selection leading to maximum efficiency.

The base population may be obtained using any one of the options that breeders of this species use. Nevertheless, the ideal situation is involvement of parents with good proven performance in crosses whenever possible; in other words, promote crossing of good $\times$ good $[9,31,32]$. As a suggestion, the segregating population will be obtained by means of hybridizations involving the ten best inbreds available. These inbreds would be chosen in terms of the higher performance, already mentioned, in yield, pest resistance and grain quality. Ideally they would be derived from different breeding programs in existence. 


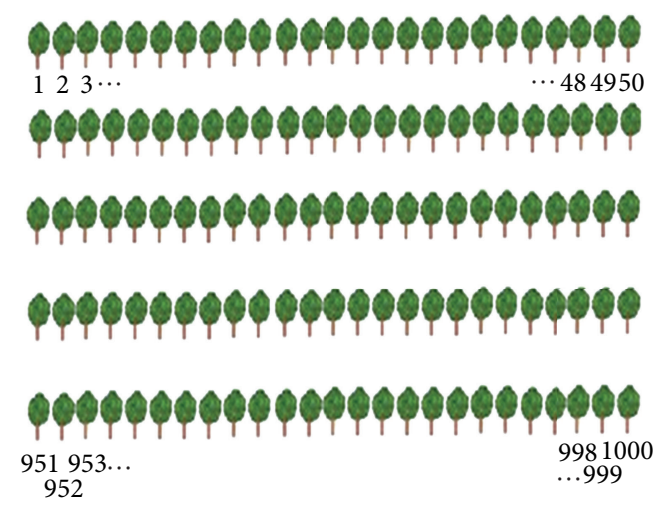

(a)

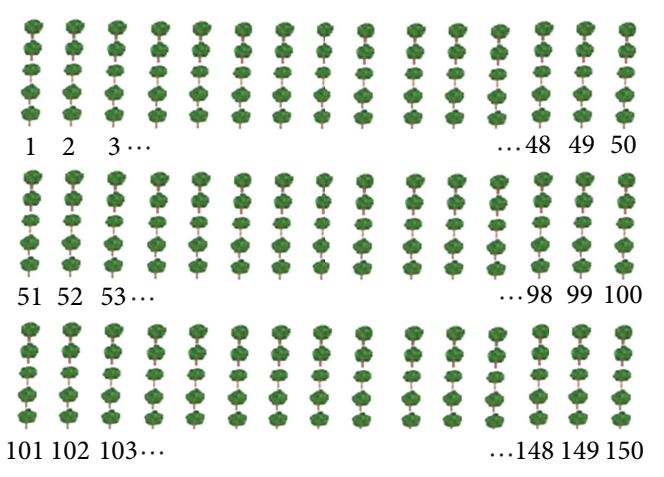

(b)

FIGURE 4: Schematic drawing for progression of generations considering the $\mathrm{F}_{2}$ generation (a) and the $\mathrm{F}_{5: 6}$ generation (b).

TABLE 1: Number of harvests for each generation in the genealogical method of the coffee tree at the time of obtaining $\mathrm{F}_{6: 7}$ progenies.

\begin{tabular}{|c|c|c|c|c|c|}
\hline & \multicolumn{5}{|c|}{ Generations } \\
\hline & $\mathrm{F}_{2}$ & $\mathrm{~F}_{2: 3}$ & $\mathrm{~F}_{3: 4}$ & $\mathrm{~F}_{4: 5}$ & $\mathrm{~F}_{5: 6}$ \\
\hline \multirow{5}{*}{ Number of harvests } & 12 & 10 & 8 & 6 & 4 \\
\hline & 7 & 5 & 3 & 1 & \\
\hline & 5 & 3 & 1 & & \\
\hline & 3 & 1 & & & \\
\hline & 1 & & & & \\
\hline
\end{tabular}

Diallel crosses could be carried out or, to facilitate, top crosses in which each inbred is a tester of all the others. The $\mathrm{F}_{1}$ seeds obtained from each top cross would be mixed, in equal amounts, obtaining 10 segregating populations (Figure 3 ). The generation $\mathrm{F}_{1}$ plants would be sown in crop conditions. In the first harvest, at two years, the seeds from each $F_{1}$ plant would be mixed in equal proportion for obtaining the $\mathrm{F}_{2}$ population. In this case, at least $100 \mathrm{~F}_{2}$ plants from each top cross would be used, making up a total population of 1000 plants (Figure 4(a)). These plants would be identified. In the first harvest, a mild selection would be carried out, for example, using selection intensity of 50\%, in other words, 500 individuals. Three seedlings per plant would be obtained from each individual selected to give rise to the $\mathrm{F}_{2: 3}$ population. This would be carried out in the field using plots of one plant with three replications, in other words, 1500 total plants.

Each $\mathrm{F}_{2}$ plant that gave rise to the $\mathrm{F}_{2: 3}$ progeny would be identified and the assessments would be continued every year. This process would be repeated for all the progenies.

In the case of $F_{2: 3}$, selection would not be carried out. Each plant would give rise to three $\mathrm{F}_{3: 4}$ plants. The $\mathrm{F}_{3: 4}$ progenies would also be conducted in a similar way to $\mathrm{F}_{2: 3}$. The assessments could be performed in more locations, three for example, using 4500 plants by location.

In this generation, in each location, the best 300 individuals would be selected for obtaining $\mathrm{F}_{4: 5}$ progenies. The decision, in this case, would be carried out considering the performance and genealogy of the $\mathrm{F}_{2}, \mathrm{~F}_{2: 3}$, and $\mathrm{F}_{3: 4}$ plants that gave rise to each individual, using the mixed model approach. Note, for example, that in the case of the $\mathrm{F}_{2}$ plant, five crop seasons would already have been performed, for $\mathrm{F}_{2: 3}$, three, and for $\mathrm{F}_{3: 4}$, one (Table 1). The $300 \mathrm{~F}_{4: 5}$ progenies selected would be assessed considering one plant per plot, ten replications, in three locations.

In selection of $\mathrm{F}_{4: 5}$ progenies, data from two harvests of this generation would be used, four from $\mathrm{F}_{3: 4}$, six from $\mathrm{F}_{2: 3}$, and eight from $\mathrm{F}_{2}$. At the time of analysis, data from all the generations and from the three locations in which the $\mathrm{F}_{4: 5}$ progenies were assessed would be used. Based on the analyses, $150 \mathrm{~F}_{5: 6}$ progenies would be selected. They would then come to be assessed in plots with five plants and five replications (Figure 4(b)). Here the progenies would also be assessed in at least three locations. In this case, the progenies would be assessed after four harvests, in order to have two biennia and thus have more assurance in the matter of the biennial nature of the crop, the change in yield from one year to the next, which is common in perennial plants. Thus, in deciding on the progenies (now a inbred because most of the loci would be in homozygosis) to be chosen, the data of the $\mathrm{F}_{5: 6}, \mathrm{~F}_{4: 5}, \mathrm{~F}_{3: 4}, \mathrm{~F}_{2: 3}$, and $\mathrm{F}_{2}$ generations would be considered (Table 1). Note that the decision for choice of the best inbred in the $\mathrm{F}_{5: 6}$ generation would have 40 harvests and more data from some locations as a reference.

All the breeding programs should be as dynamic as possible. The proposal presented presupposes that the inbreds will go to the value for cultivation and use (VCU) after 18 years. Clearly, this procedure is not able to meet the needs of the coffee agribusiness in Brazil. It is necessary to make new inbreds available every four or five years. 
The way of achieving this goal is by means of a recurrent selection program using the strategy already mentioned. For that purpose, $\mathrm{F}_{3: 4}$ progenies would be selected after two harvests. In selection, the ten best, preferentially arising from top cross with different parents would be intercrossed in a manner similar to that mentioned above (Figure 3). If some new inbred arose derived from other breeding programs or showed resistance to pests or pathogens, they could and should be included in recombination process. The procedure as of that point will be similar to that which was detailed previously. With this strategy after the first cycle, new inbred may be obtained every four to five years, making the program much more efficient.

This strategy has some advantages. (i) It allows more dynamism in breeding programs of perennial plants such as coffee crop. The proposal is appropriate for a recurrent selection program. As of the $\mathrm{F}_{3: 4}$ generation, the best progenies may be recombined and also inbreds from other programs and sources of resistance to pests and pathogens should be included in recombination. (ii) Deciding upon the best progenies in each stage, especially as of $\mathrm{F}_{3: 4}$, is more accurately performed [24] because the number of replications involved in the process is enormous. (iii) Greater possibility for identifying progenies with greater stability and adaptability. From what was mentioned above, this fact is clear. It should be stressed that stability may be assessed both in the context of years and locations and also in the alternating nature of yield every two years. (iv) A great deal of information that may assist future decisions of breeders may be assessed, as, for example, comparing the interactions of progenies $\times$ years and progenies $\times$ locations. Various alternatives for analyses may be assessed, as, for example, use of the least square method and the mixed model method, especially the BLUP [23], moving averages $[33,34]$, sequential analysis with the use of BLUP [35], and others. In this case, moreover, genealogy may be used as an additional criteria, as was mentioned previously. Genomic selection, which has received a great deal of attention recently [36], may have its efficiency proven in breeding of perennial plants. It may also be used in obtaining estimates of genetic and phenotypic components, especially realized heritability, which is not frequent in the case of coffee crop, and many other alternatives that would allow the breeder in the future to make decisions with a greater deal more certainty.

\section{Acknowledgments}

The authors wish thank to the Conselho Nacional de Desenvolvimento Científico e Tecnológico (CNPq) and Coordenação de Aperfeiçoamento de Pessoal de Ensino Superior (CAPES) for financial support.

\section{References}

[1] M. A. P. Ramalho, A. F. B. Abreu, and J. B. Santos, "Melhoramento de espécies autógamas," in Recursos Genéticos e Melhoramento: Plantas, L. L. Nass, A. C. C. Valois, I. S. Melo, and M. C. Valadares-Inglis, Eds., pp. 201-230, Fundação MT, Rondonópolis, Brazil, 2001.
[2] R. Vencovsky and M. A. P. Ramalho, "Contribuições do melhoramento de plantas no Brasil," in Ciência, Agricultura e Sociedade, E. Paterniani, Ed., pp. 41-74, EMBRAPA, Brasília, Brazil, 2006.

[3] R. A. Fischer and G. O. Edmeades, "Breeding and cereal yield progress," Crop Science, vol. 50, pp. 85-98, 2010.

[4] M. S. Lopes, M. P. Reynolds, Y. Manes, R. P. Singh, J. Crossa, and H. J. Braun, "Genetic yield gains and changes in associated traits of cimmyt spring bread wheat in a "historic" set representing 30 years of breeding," Crop Science, vol. 52, no. 3, pp. 1123-1131, 2012.

[5] N. F. Jensen, Plant Breeding Methodology, John Wiley \& Sons, New York, NY, USA, 1988.

[6] R. W. Allard, Principles of Plant Breeding, John Wiley \& Sons, New York, NY, USA, 2nd edition, 1999.

[7] F. J. Muehlbauer, D. G. Burnell, T. P. Bogyo, and M. T. Bogyo, "Simulated comparisons of single seed descent and bulk population breeding methods," Crop Science, vol. 21, no. 2, pp. 575-577, 1981.

[8] W. R. Fehr, "Principles of cultivar development," in Theory and Technique, vol. 2, p. 761, Macmillan, New York, NY, USA, 1987.

[9] M. A. P. Ramalho, A. F. B. Abreu, J. B. Santos, and J. A. R. Nunes, Aplicações da Genética Quantitativa no Melhoramento de Plantas Autógamas, Editora UFLA, Lavras, Brazil, 2012.

[10] J. S. Beaver and J. D. Kelly, "Comparison of selection methods for dry bean populations derived from crosses between gene pools," Crop Science, vol. 34, no. 1, pp. 34-37, 1994.

[11] F. V. Raposo, M. A. P. Ramalho, and A. F. B. Abreu, "Comparação de métodos de condução de populações segregantes do feijoeiro," Pesquisa Agropecuária Brasileira, vol. 35, no. 10, pp. 1991-1997, 2000.

[12] J. Miladonovic, J. W. Burton, S. Balesevic Tubic, D. Miladinovic, V. Djordjevic, and V. Djukic, "Soybean breeding: comparison of the efficiency of different selection methods," Turkish Journal of Agriculture and Forestry, vol. 35, pp. 469-480, 2011.

[13] P. S. J. Santos, A. F. B. Abreu, and M. A. P. Ramalho, "Seleção de linhas puras no feijão 'Carioca”, Ciência e Agrotecnologia, pp. 1492-1498, 2002.

[14] A. F. Chiorato, S. A. M. Carbonell, L. A. D. S. Dias, and M. D. V. de Resende, "Prediction of genotypic values and estimation of genetic parameters in common bean," Brazilian Archives of Biology and Technology, vol. 51, no. 3, pp. 465-472, 2008.

[15] M. R. Petek, T. Sera, and I. C. B. Fonseca, "Predição de valores genéticos aditivos na seleção visando obter cultivares de café mais resistentes à ferrugem," Bragantia, vol. 67, no. 1, pp. 133-140, 2008.

[16] I. Bos and P. Caligari, Selection Methods in Plant Breeding, Springer, Dordrecht, The Netherlands, 2008.

[17] A. R. Hallauer, M. J. Carena, and J. B. Miranda Filho, Quantitative Genetics in Maize Breeding, Springer, New York, NY, USA, 3rd edition, 2010.

[18] W. H. Meyers and N. Kalaitzandonakes, "World population and food supply," in The Role of Biotechnology in Sustainable Food Supply, J. S. Popp, M. M. Jahn, M. D. Matlock, and N. P. Kemper, Eds., p. 296, Cambridge University Press, New York, NY, USA, 2012.

[19] D. Tilman, C. Balzer, J. Hill, and B. L. Befort, "Global demand and sustainable intensification of agriculture," Proceedings of the National Academy of Sciences of the United States of America, vol. 108, no. 50, pp. 20260-20264, 2011. 
[20] J. Brown and P. Caligari, An Introduction to Plant Breeding, Blackwell Publishing, Oxford, UK, 2011.

[21] J. A. R. Nunes, M. A. P. Ramalho, and D. F. Ferreira, "Inclusion of genetic relationship information in the pedigree selection method using mixed models," Genetics and Molecular Biology, vol. 31, no. 1, pp. 73-78, 2008.

[22] C. R. Henderson, Applications of Linear Models in Animal Breeding, vol. 23, University of Guelph, Guelph, Canada, 1984.

[23] M. D. V. Resende, Genética biométrica e estatística no melhoramento de plantas perenes, Editora Embrapa-SCT, Brasília, Brazil, 2002.

[24] M. D. V. Resende, Matemática e estatística na análise de experimentos e no melhoramento genético, EMBRAPA Florestas, Colombo, Sri Lanka, 2007.

[25] R. A. Mrode and R. Thompson, Linear Models for the Prediction of Animal Breeding Values, CABI, Wallingford, Conn, USA, 2nd edition, 2005.

[26] T. L. White and G. R. Hodge, Predicting Breeding Values with Applications in Forest Tree Improvement, Kluwer Academic, Dodrecht, The Netherlands, 1989.

[27] A. Carvalho and L. C. Fazuoli, "Café," in Melhoramento de plantas no Instituto Agronômico, A. M. C. Furlani and G. P. O. Viégas, Eds., pp. 29-76, Instituto Agronômico, Campinas, Brazil, 1993.

[28] N. S. Sakiyama, A. A. Pereira, W. M. Moura, and L. Zambolim, "Melhoramento do café arábica," in Melhoramento de espécies cultivadas, A. Borém, Ed., pp. 203-223, UFV, Viçosa, Brazil, 2005.

[29] R. Bernardo, Breeding for Quantitative Traits in Plants, Stemma Press, Woodbury, Minn, USA, 2010.

[30] T. Sera, "Coffee genetic breeding at Iapar," Crop Breeding and Applied Biotechnology, vol. 1, no. 2, pp. 179-200, 2001.

[31] D. C. Rasmusson and R. L. Phillips, "Plant breeding progress and genetic diversity from de novo variation and elevated epistasis," Crop Science, vol. 37, no. 2, pp. 303-310, 1997.

[32] J. W. Dudley, "Quantitative genetics and plant breeding," Advances in Agronomy, vol. 59, pp. 1-23, 1997.

[33] F. R. Clarke and R. J. Baker, "Spatial analysis improves precision of seed lot comparisons," Crop Science, vol. 36, no. 5, pp. 1180-1184, 1996.

[34] E. A. Souza, I. O. Geraldi, and M. A. P. Ramalho, "Alternativas experimentais na avaliação de famílias em progrmas de melhoramento genético do feijoeiro," Pesquisa Agropecuária Brasileira, vol. 35, no. 9, pp. 1765-1771, 2000.

[35] H. P. Piepho, J. Möhring, A. E. Melchinger, and A. Büchse, "BLUP for phenotypic selection in plant breeding and variety testing," Euphytica, vol. 161, no. 1-2, pp. 209-228, 2008.

[36] R. Bernardo, "Molecular markers and selection for complex traits in plants: learning from the last 20 years," Crop Science, vol. 48, no. 5, pp. 1649-1664, 2008. 

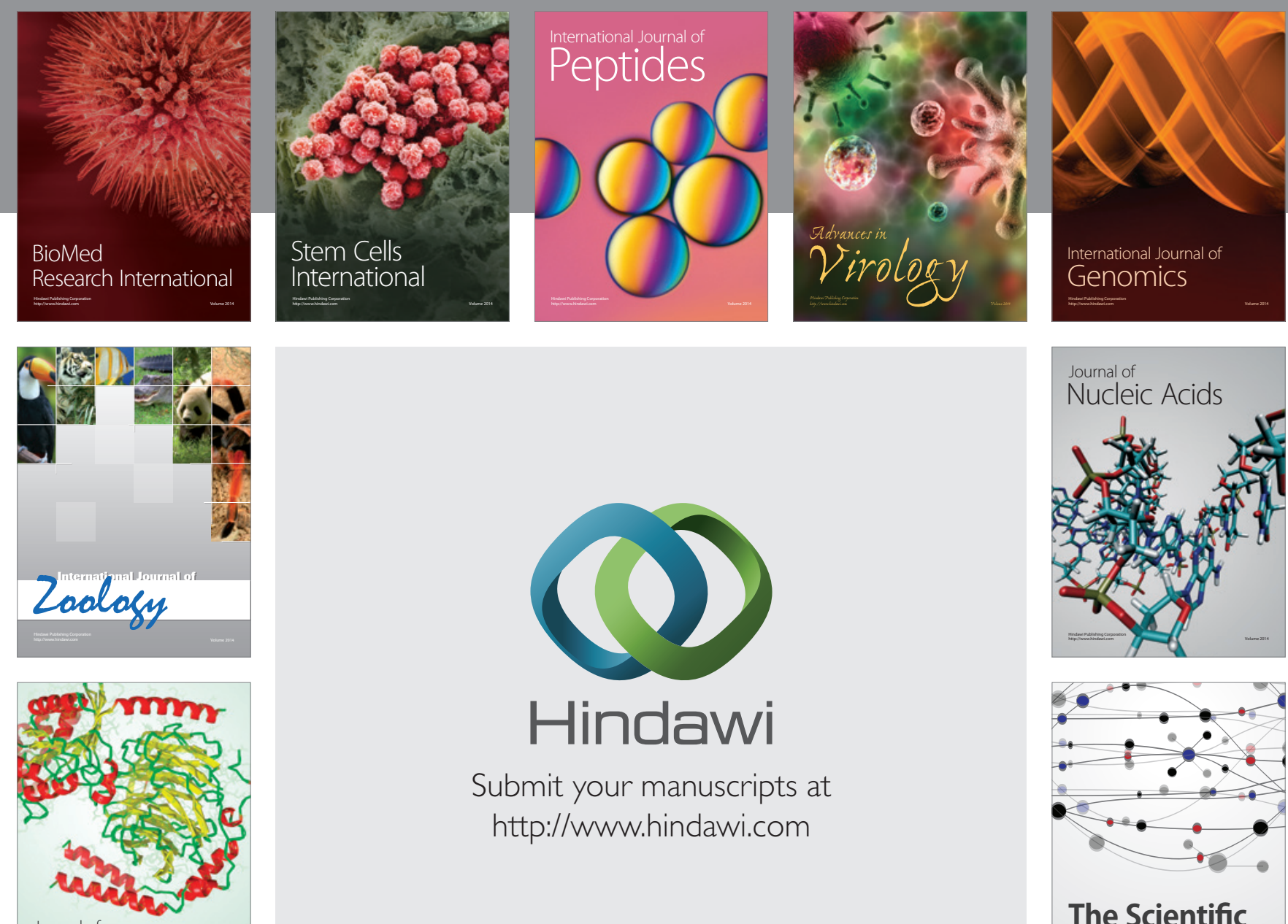

Submit your manuscripts at

http://www.hindawi.com

Journal of
Signal Transduction
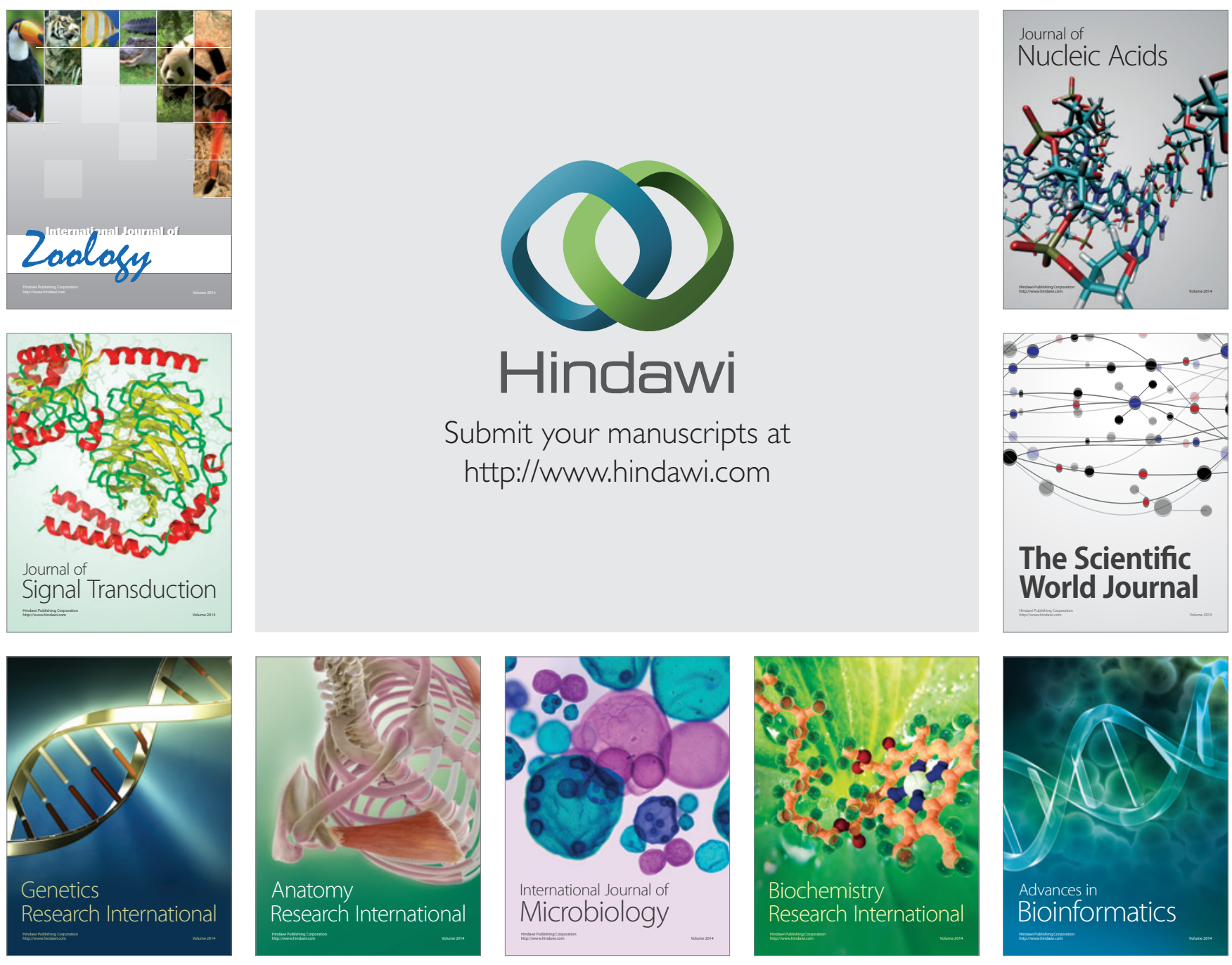

The Scientific World Journal
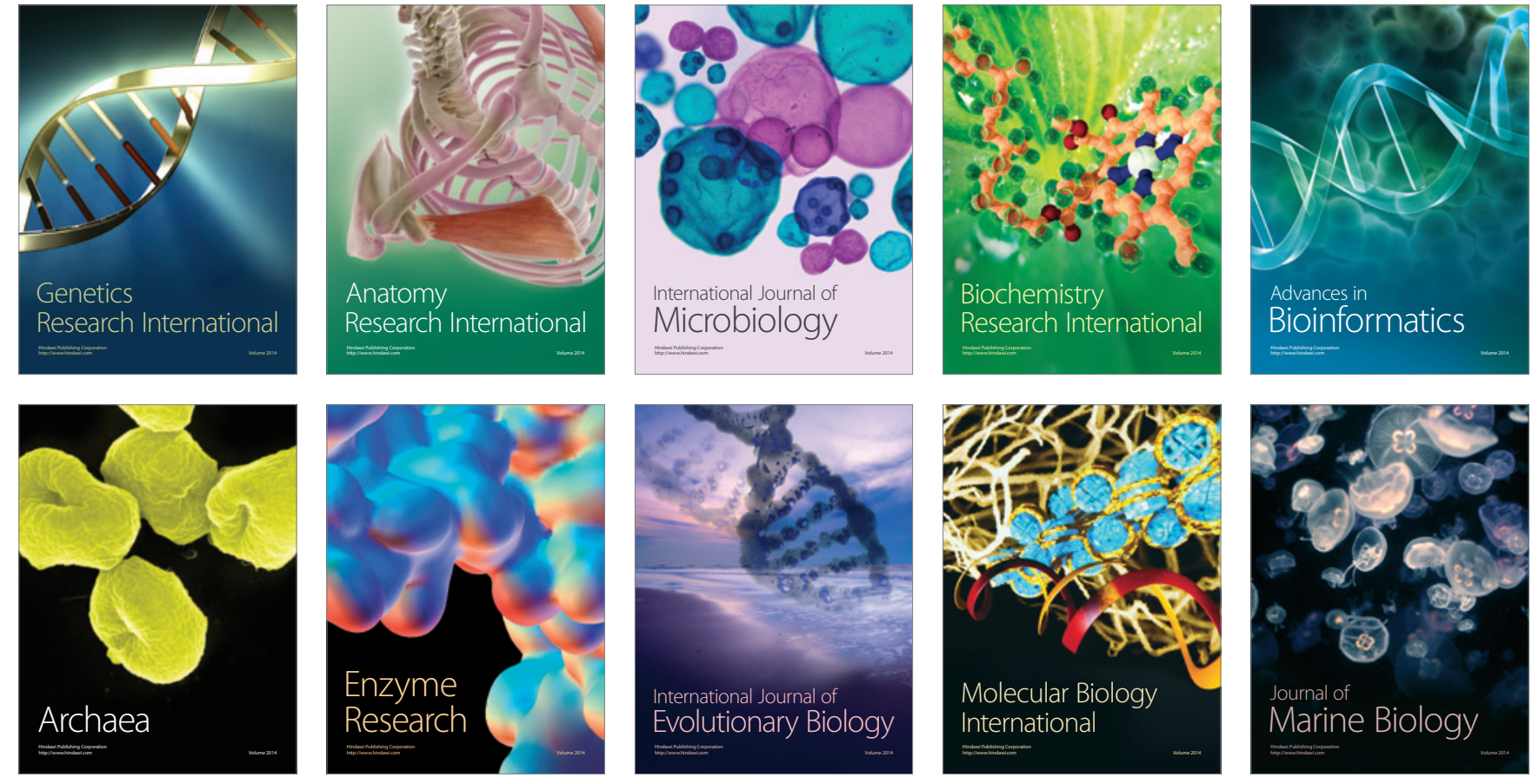